ISSN 1392-3196 / e-ISSN 2335-8947

Zemdirbyste-Agriculture, vol. 107, No. 4 (2020), p. 373-382

DOI $10.13080 / \mathrm{z}-\mathrm{a} .2020 .107 .048$

\title{
A comparison of fruit and leaf parameters of apple in three orchard training systems
}

\author{
Ahmed EZZAT $^{1}$, Ali R. EL-SHERIF ${ }^{1}$, Doaa ELGEAR ${ }^{1}$, Szilárd SZABÓ2 ${ }^{2}$ Imre J. HOLB ${ }^{3,4}$ \\ ${ }^{1}$ Kafelelsehikh University, Faculty of Agriculture, Department of Horticulture \\ Kafr El-Shaikh, Egypt \\ ${ }^{2}$ University of Debrecen, Department of Physical Geography and Geoinformatics \\ Egyetem tér 1, 4032 Debrecen, Hungary \\ ${ }^{3}$ University of Debrecen, Faculty of Agronomy, Institute of Horticulture \\ P.O. box 36, 4015 Debrecen, Hungary \\ E-mail: holb@agr.unideb.hu \\ ${ }^{4}$ Hungarian Academy of Sciences, Centre for Agricultural Research, Plant Protection Institute \\ Herman Ottó út 15, 1022 Budapest, Hungary
}

\begin{abstract}
In a two-year study, the effects of three training systems on apple fruit and leaf parameters: 9 fruit yield, 8 physicochemical and 4 antioxidant capacity related parameters and the relationships among 11 yield quality parameters, of the apple cultivar 'Royal Gala' were studied. In addition, light penetration into the tree canopy was determined. The investigated three training systems were Oblique Palmette (1250 trees ha $\left.{ }^{-1}\right)$, Bibaum (1923 trees ha- $\left.{ }^{-1}\right)$ and Slender Spindle (1666 trees ha-1). Light penetration into the tree canopy, fruit number per tree, fruit weight, fruit yield, fruit skin colour, fruit firmness, starch index of fruit, $\mathrm{N}$ - and $\mathrm{K}$-contents of leaves as well as ascorbic acid content, total anthocyanins and total antioxidant capacity of fruit indicated significant differences $(P<0.05)$ amongst the training systems, but the differences were not significant between experimental years. The Bibaum gave the highest values for light penetration into the tree canopy, fruit number per tree, fruit yield, fruit skin colour, starch index of fruit, N- and K-contents of leaves and total anthocyanins, which were significantly different from those of the Oblique Palmette or the Slender Spindle. The Slender Spindle gave the highest values for fruit weight, fruit firmness and total antioxidant capacity, which were significantly different from those of the Bibaum. Fruit of the Oblique Palmette trained trees showed the highest ascorbic acid content, which was significantly different from that of the Slender Spindle but not from the Bibaum. From the 55 correlation pairs of each training system, 27, 17 and 15 were significant at $P<0.05$ in the Oblique Palmette, the Bibaum and the Slender Spindle, respectively. Only five correlation pairs were significant in all the three training systems. This study clearly demonstrated that most of the parameters were largely affected by the training systems, which may influence apple growing practices and fruit quality in a given orchard training system.
\end{abstract}

Key words: antioxidant capacity, fruit quality parameters, light penetration, plant health status, training system, yield parameters.

\section{Introduction}

The use of a suitable training system with appropriate pruning and bending was proved to be an efficient fruit growing practice in order to reach optimum yield and improve fruit quality (Fallahi et al., 2018). Pruning is a key component to maintain training system during the orchard lifetime and ensures a balance between tree growth and fruit yield, which is based on the fundamental knowledge that fruit yield negatively correlates with tree growth (Gandev, Dzhuvinov, 2014). Fruit yield and quality are highly dependent on the light penetration into the tree canopy (Dallabetta et al., 2017).

Light within the tree canopy is highly dependent on tree density in the orchard (Gandev, Dzhuvinov, 2014), which is a key factor in designing orchard training systems (Sander et al., 2019). The availability of light and the distribution of light within the canopy are significantly better in a high-density orchard with large numbers of smaller trees per area unit compared to a low-density orchard with lower numbers of larger trees per area unit. Dwarf trees in a closer spacing intercept a greater proportion of the incoming light, as the leaf area spreads more uniformly within the tree all over the orchard, which

Please use the following format when citing the article:

Ezzat A., El-Sherif A. R., Elgear D., Szabó S., Holb I. J. 2020. A comparison of fruit and leaf parameters of apple in three orchard training systems. Zemdirbyste-Agriculture, 107 (4): 373-382. DOI 10.13080/z-a.2020.107.048 
results in an overall better fruit yield (Gandev et al., 2016). On the other hand, larger trees had more shaded canopies, which results in lower flower bud induction, spur quality, fruit colour, fruit size and internal quality compared to smaller trees (Crassweller, Smith, 2017).

One of the most commonly used high-density training systems is the Slender Spindle, which was designed for improving orchard management by allowing most of the agriculture practices to be done from the ground (Wertheim et al., 2001). Therefore, trees were designed with a canopy width of less than $2 \mathrm{~m}$ with a conical shape. Due to smaller trees, space distances between rows can be reduced in the Slender Spindle, but fruit quality reduced in the inner and lower parts of the trees due to shading (Crassweller, Smith, 2017). Therefore, modifications were applied to the Slender Spindle for increasing light exposure into the tree and light interception in the field.

Trees in some other training systems such as the Oblique Palmette were reported to have better light penetration into the canopy than into the Slender Spindle trees (Gandev, Dzhuvinov, 2014); however, the light transmission in the Oblique Palmette shaped trees is the same as that of the Slender Spindle, if the growers keep the trees in a narrow width.

Another training system, the Bibaum one, is formed by growing two (bi-axis) leaders. This gave the opportunity either to enhance light exposure (Dorigoni et al., 2011). Several studies documented the light availability in various apple orchards and the consequences for several fruit parameters such as yield and size (Holb et al., 2012; Reig et al., 2019; Sander et al., 2019), physico-chemical parameters (Jung, Choi, 2010), fruit quality attributes including phenolic compounds, anthocyanin content and antioxidant capacity (Vieira et al., 2011; Dallabetta et al., 2017). In addition, correlations among fruit yield and quality attributes were also studied in some previous studies (Sun et al., 2002; Hülya, 2007; Saei et al., 2011; Ornelas-Paz et al., 2018). However, these parameters were determined mostly at harvest, and only few of the above studies focused on the temporal patterns of the parameters during the season, especially under continental climate conditions. Nevertheless, this may provide a better understanding of the known fruit quality differences among the training systems.

The aim of the study was to evaluate the effects of three training systems on apple fruit and leaf parameters: 9 fruit yield, 8 physico-chemical and 4 antioxidant capacity related parameters, and the relationships among 11 fruit parameters of the apple cultivar 'Royal Gala'. In addition, light penetration into the tree canopy of the orchard was determined in the three training systems.

All 22 parameters are essential measurements for an appropriate comparison of the three orchard systems, which also provide background information from an economic point of view. However, only those 11 fruit parameters were selected for correlation analyses, which could show potential influence on fruit yield and quality in the comparison of the three training systems.

\section{Materials and methods}

Orchard site and training systems. This study was carried out in a 3.5 ha commercial apple (Malus domestica Borkh.) orchard located in Nyíregyháza, Eastern Hungary during the two seasons of 2015 and
2016. The orchard was established in 2011 with the apple cultivar 'Royal Gala' grafted on M.9-EMLA rootstock. Since the establishment of the orchard, the trees were treated according to the European Integrated Fruit Production Guidelines (Holb et al., 2012).

The orchard was irrigated twice a year (July and August) with a drip irrigation system. The winter pruning was performed in late winter, two summer prunings were done at the beginning of June and August, and a hand fruit thinning was performed in early June. A disc-tiller was used for weed management, when it was necessary. Synthetic fertilizers with a N-P-K 10:15:15 ratio were applied annually.

The trees were trained with three training systems. 1. Oblique Palmette: trees had a central axis and regular tiers of branches that were grown up across wires at an oblique angle $\left(30^{\circ}\right)$ (Gandev, Dzhuvinov, 2014); trees were grown with a planting distance between rows of $4 \mathrm{~m}$ and within rows of $2 \mathrm{~m}$ (1250 trees ha- $\left.\mathrm{ha}^{-1}\right)$. 2. Bibaum: trees had two balanced and symmetric axes on one trunk according to Dorigoni et al. (2011); trees were grown with a planting distance between rows of 4 $\mathrm{m}$ and within rows of $1.3 \mathrm{~m}\left(1923\right.$ trees $\left.\mathrm{a}^{-1}\right)$. 3. Slender Spindle: trees were trained conventionally according to Wertheim et al. (2001); trees were grown with a planting distance between rows of $4 \mathrm{~m}$ and within rows of $1.5 \mathrm{~m}$ (1666 trees ha $\left.{ }^{-1}\right)$.

Light penetration into the tree canopy. Light that penetrated into the tree canopy and reached the orchard floor was determined. Therefore, the available light was measured under the tree canopy at $10 \mathrm{~cm}$ above the orchard floor in the centre of the tree. Measurements were made in four replicates daily between 10.00 a.m. and $12.00 \mathrm{~h}$ in the period between 1 April and 31 August in both years. Daily data were averaged monthly and then the two experimental years were combined. The available light was measured with a digital light meter LX1330B (Qandies Limited, UK) and expressed as lux, equal to a luminous flux of 1 lumen $\mathrm{m}^{-2}$.

Fruit yield and size. Five randomly selected trees replicated four times were used to determine fruit yield parameters at harvest (23 August 2015 and 25 August 2016) in all the three training systems. Fruit number per tree was counted, fruit weight was measured on 30 fruits per tree and fruit yield per tree was determined as $\mathrm{kg}$ per tree. Then, fruits from each selected tree were grouped in 6 fruit size $(\mathrm{mm})$ categories as follows: $1-60-65,2-65$ $70,3-70-75,4-75-80,5-80-85$ and $6-85-90$. Data was expressed as a percentage of fruit in each category.

Fruit sampling for measuring physico-chemical and antioxidant capacity related parameters. From the $5 \times 4$ selected trees, fifty fruit samples per replicate (including 5 trees) were collected randomly in each year and in each training system for the fruit measurements. Physico-chemical parameters were measured on the fresh fruit samples, then the samples were lyophilized for measuring their antioxidant capacity related parameters.

Physico-chemical parameters of fruits were measured in four replicates. Fruit firmness as penetration force (Newton) was measured by a Magness Tazlor penetrometer FT011 (QA Supplies LLC, Italy). Fifty fruits per replicate were measured for fruit firmness every 10 days from 1 June until harvest date.

Soluble solid content (SSC, ${ }^{\circ}$ Brix) of fruit juice was measured by a portable digital refractometer 53007 (TR Turoni Inc., Italy) at $25^{\circ} \mathrm{C}$ temperature. Juice acidity 
(\%) was measured by a portable digital acidity meter 53101 (TR Turoni Inc.). Fruit skin colour was observed visually on 50 fruits per replicate and graded from green ( 0 score) to red ( 5 scores) colours: green -0 , yellowish green -1 , yellow -2 , yellowish red -3 , reddish yellow -4 and red -5 .

The starch index was measured in four replicates (50 fruits per replicate) for each training system in both experimental years from 10 July until harvest, every 10 days. The starch index was expressed in a 9-scale classification grade: index $1,2,3,4,5,6,7,8$ and 9 for $100,80,70,60,50,30,20,10$ and $0 \%$ dark stained fruit. Index 1 represents high starch content in an immature fruit, and index 9 indicates starch content close to zero on a matured fruit.

Nitrogen $(\mathrm{N})$, phosphorus $(\mathrm{P})$ and potassium (K) contents were measured in 50 leaves per tree in the $5 \times 4$ tree samples for each year in July and each training system. Total N-content was measured using the Kjeldahl procedure. Total P-content was determined as MVPA (molybdovanadophosphoric acid) and was read at $470 \mathrm{~nm}$ on a spectrophotometer UV 1280 (Shimadzu, Japan). Total K-content was determined by a flame spectrophotometer according to Yang et al. (2010).

Antioxidant capacity related parameters of fruits. Fifty fruit samples in four replicates were lyophilized and used for each antioxidant capacity related parameter and for all training systems in each year. The ascorbic acid content was determined with the DNPH (dinitrophenylhydrazine) method according to Al-Ani et al. (2007) and was expressed as $100 \mathrm{~g}^{-1}$ of fresh weight $(\mathrm{FW})$. Total monomeric anthocyanins were determined with the $\mathrm{pH}$-differential method according to Qin et al. (2010) and were expressed as CGE (cyanidin3 -glucoside) equivalent $100 \mathrm{~g}^{-1}$ of $\mathrm{FW}$. The total antioxidant capacity of fruit was measured with the FRAP (ferric reducing antioxidant power) method according to Oszmiański et al. (2015). The reduction of the $\mathrm{Fe}^{3+}-\mathrm{TPTZ}$ (2,4,6-Tris(2-pyridyl)-s-triazine) complex to the ferrous form at low $\mathrm{pH}$ was monitored by determining the absorption change at $593 \mathrm{~nm}$. Then, the measured value of the total antioxidant capacity was expressed as mg equivalents of ascorbic acid (AA) of fresh weight (mg AA $\mathrm{g}^{-1} \mathrm{FW}$ ). The total amount of soluble phenols was measured with the method of Ainsworth and Gillespie (2007) by using Folin-Ciocalteu's reagent. Then, the soluble phenols content was determined from a standard curve obtained from various concentrations of gallic acid.

Statistical analysis. The data of light penetration and 21 fruit and leaf parameters at harvest were used to evaluate the three training systems in the two experimental years. All measurements were averaged to obtain a single value for each year and training system. Then, data of each measurement were analysed by analysis of variance in order to evaluate the effect of year and training system and their interaction. Time series data of light penetration, fruit firmness and starch index were also subjected to analyses of variance in order to evaluate the effect of year, training system and assessment date and their interactions. Means for each measurement were separated by an unprotected least significant difference (LSD) test using $\mathrm{LSD}_{0.05}$ values. Prior to the analyses, incidence values were arcsine-square root transformed in order to make the data normally distributed. Pearson's correlations among 11 yield quality parameters were also calculated for the combined data of the two years but separately for the three training systems. In the correlation analyses, $2 \times 30$ data $(n=60)$ were used for each correlation pair as the two-year data were combined. All analyses were done using software Genstat 5, version 4.1 (Lawes Agricultural Trust, IACR, UK).

\section{Results}

Light penetration into the tree canopy. Temporal analyses of the measurement showed that light penetration decreased from April until August during the season in all the three training systems (Fig. 1). The Bibaum training system showed the highest values of the measurement, which were significantly higher compared to the two others except for April and June. The measurement was significantly different between the Oblique Palmette and the Slender Spindle training systems only in April and July.

Fruit yield and size. Analyses of variance of the fruit number, weight and yield indicated significant differences amongst the three training systems, but the differences were not significant between the experimental

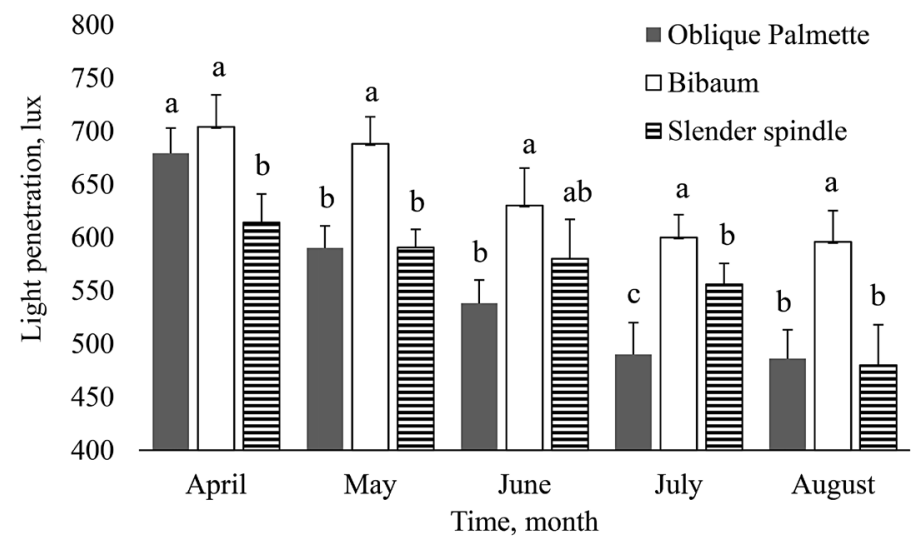

Note. Data sets are combined for 2015 and 2016, and monthly means of daily data are presented in the columns; error bars represent the average standard error values; different letters above the bars correspond to significant differences at $P<0.05$ between the training systems separately for each month, using a least significant difference test.

Figure 1. The effect of the three training systems on light penetration into the tree canopy during the assessment period (2015 and 2016) 
years. There were no significant interactions amongst treatment factors. Mean fruit number per tree was significantly higher in the Bibaum at harvest compared to either Oblique Palmette or Slender Spindle trees (Table 1). Mean fruit weight was significantly different between the Slender Spindle and the Bibaum or the Oblique
Palmette at harvest. Mean fruit weight was the lowest in the Oblique Palmette trained trees and the highest in the Slender Spindle ones. The fruit yield was the highest in the Bibaum, but showed no significant difference from the Slender Spindle, while it was significantly lower in the Oblique Palmette trained trees.

Table 1. The effect of the three training systems on yield parameters of apple fruits at harvest (2015 and 2016)

\begin{tabular}{|c|c|c|c|c|c|c|c|c|c|}
\hline \multirow{2}{*}{ Training system } & \multirow{2}{*}{$\begin{array}{l}\text { Number, } \\
\text { piece tree }\end{array}$} & \multirow{2}{*}{$\begin{array}{c}\text { Weight } \\
\mathrm{g}\end{array}$} & \multirow{2}{*}{$\begin{array}{l}\text { Yield } \\
\text { kg tree }^{-1}\end{array}$} & \multicolumn{6}{|c|}{ Percentage of fruit size categories $\mathrm{mm}$} \\
\hline & & & & $60-65$ & $65-70$ & $70-75$ & $75-80$ & $80-85$ & $85-90$ \\
\hline Oblique Palmette & $52.1 \mathrm{bb}$ & $142.1 \mathrm{~b}$ & $7.40 \mathrm{~b}$ & $17.8 \mathrm{a}$ & $24.4 \mathrm{a}$ & $40.6 \mathrm{a}$ & $9.0 \mathrm{c}$ & 5.6 & 3.6 \\
\hline Bibaum & $59.3 \mathrm{a}$ & $144.4 \mathrm{~b}$ & $8.56 \mathrm{a}$ & $15.0 \mathrm{a}$ & $27.0 \mathrm{a}$ & $23.8 \mathrm{~b}$ & $25.8 \mathrm{~b}$ & 4.4 & 4.0 \\
\hline Slender Spindle & $55.2 \mathrm{~b}$ & $149.2 \mathrm{a}$ & $8.23 \mathrm{ab}$ & $6.2 \mathrm{~b}$ & $10.2 \mathrm{~b}$ & $35.4 \mathrm{a}$ & $41.4 \mathrm{a}$ & 4.1 & 2.8 \\
\hline $\operatorname{LSD}_{0.05}$ & 3.2 & 4.2 & 1.2 & 8.7 & 9.6 & 11.4 & 12.8 & ns & ns \\
\hline
\end{tabular}

Note. Data are means of 2015 and 2016 due to the non-significant effect of years in the analysis of variance; the same letters in the columns are not significantly different at $P<0.05$ among the training systems.

Analyses of variance of the fruit size categories 60-65, 65-70, 70-75 and 75-80 mm indicated significant differences amongst the training systems, but the differences were not significant between years. While the analyses of variance of the fruit size categories $80-85$ and 85-90 $\mathrm{mm}$ showed no significant differences either for the years or for the training systems. Categorization of fruit size from the investigated training systems showed that for the Oblique Palmette the majority of fruit $(82.8 \%)$ was between the size of 60 and $75 \mathrm{~mm}$, while for the Bibaum the majority of fruit $(76.6 \%)$ was between the size of 65 and $80 \mathrm{~mm}$ (Table 1). In the Slender Spindle, $76.8 \%$ of the harvested fruit were between 70 to $80 \mathrm{~mm}$ : $35.4 \%$ for $70-75 \mathrm{~mm}$ and $41.4 \%$ for $75-80 \mathrm{~mm}$.

Physico-chemical parameters of fruits. Analyses of variance of fruit skin colour, fruit firmness, starch index of fruit, $\mathrm{N}$ - and $\mathrm{K}$-contents of leaves indicated significant differences amongst the training systems, but the differences were not significant between years. While soluble solid content, juice acidity and P-content of leaf showed no significant differences between the two experimental years and amongst the three training systems. Soluble solid content, juice acidity and P-content of leaf ranged between 11.2 and $12.9{ }^{\circ} \mathrm{Brix}$, between $9.8 \%$ and $11.2 \%$ and between $0.28 \%$ and $0.31 \%$, respectively, though these values were not significantly different in the three training systems (Table 2).

Mean fruit skin colour was the highest in the Bibaum, and these values in the Oblique Palmette and the Slender Spindle training systems were significantly lower compared to the Bibaum. The lowest values for mean fruit firmness was recorded for the Bibaum at harvest, which was significantly lower compared to either Oblique Palmette or Slender Spindle fruits.

Table 2. The effect of the three training systems on physico-chemical parameters of apple fruits at harvest (2015 and 2016)

\begin{tabular}{lcccccccc}
\hline \multirow{2}{*}{ Training system } & $\begin{array}{c}\text { SSC } \\
{ }^{\circ} \text { Brix }\end{array}$ & $\begin{array}{c}\text { Acidity } \\
\%\end{array}$ & $\begin{array}{c}\text { Colour } \\
(0-5)\end{array}$ & $\begin{array}{c}\text { Fruit firmness } \\
\text { N }\end{array}$ & $\begin{array}{c}\text { Starch index } \\
(1-9)\end{array}$ & $\begin{array}{c}\mathrm{N} \\
\%\end{array}$ & $\begin{array}{c}\mathrm{P} \\
\%\end{array}$ & $\begin{array}{c}\mathrm{K} \\
\%\end{array}$ \\
\hline Oblique Palmette & 12.1 & 9.8 & $3.0 \mathrm{~b}$ & $76.8 \mathrm{~b}$ & $6.2 \mathrm{ab}$ & $1.72 \mathrm{~b}$ & 0.30 & $1.32 \mathrm{ab}$ \\
Bibaum & 12.9 & 11.2 & $3.5 \mathrm{a}$ & $69.6 \mathrm{a}$ & $6.6 \mathrm{~b}$ & $1.98 \mathrm{a}$ & 0.31 & $1.46 \mathrm{a}$ \\
Slender Spindle & 11.2 & 10.5 & $2.9 \mathrm{~b}$ & $77.7 \mathrm{~b}$ & $5.4 \mathrm{a}$ & $1.68 \mathrm{~b}$ & 0.28 & $1.21 \mathrm{~b}$ \\
\multicolumn{1}{c}{ LSD $_{0.05}$} & $\mathrm{~ns}$ & $\mathrm{~ns}$ & 0.4 & 6.5 & 0.8 & 0.22 & $\mathrm{~ns}$ & 0.17 \\
\hline
\end{tabular}

Explanation under Table 1

The temporal dynamics of fruit firmness showed that firmness was continuously reduced from 1 June until harvest in all the three training systems (Fig. 2). The Bibaum showed the lowest fruit firmness values, which were significantly different form either Oblique Palmette or Slender Spindle fruits in the period between 20 June and harvest. Fruit firmness values in the Oblique Palmette and the Slender Spindle were not significantly different from each other during the whole assessment period (Table 2 and Fig. 2).

Starch index of fruit at harvest was the lowest (5.4) in the Slender Spindle, but it was significantly different (6.6) only from the Bibaum fruits (Table 2). A temporal assessment of starch index showed that fruits in the Bibaum showed the highest starch index values from 20 July until harvest, and these values were significantly different from the Slender Spindle fruits. However, the starch index of fruit in the Bibaum was significantly different from the Oblique Palmette fruits only at 20 and 30 July (Fig. 3).

$\mathrm{N}$ - and K-contents of leaves were the highest in the Bibaum. The N-content was significantly different from either the Oblique Palmette or the Slender Spindle, while K-content was significantly different only from the Slender Spindle (Table 2).

Antioxidant capacity related parameters of fruits. Analyses of variance of ascorbic acid content, total anthocyanins and total antioxidant capacity of fruit indicated significant differences $(P<0.05)$ amongst the training systems, but the differences were not significant between years (Table 3 ). While total soluble phenol content of fruit showed no significant differences $(P<0.05)$ between the two experimental years and amongst the three training systems. There were no significant interactions 


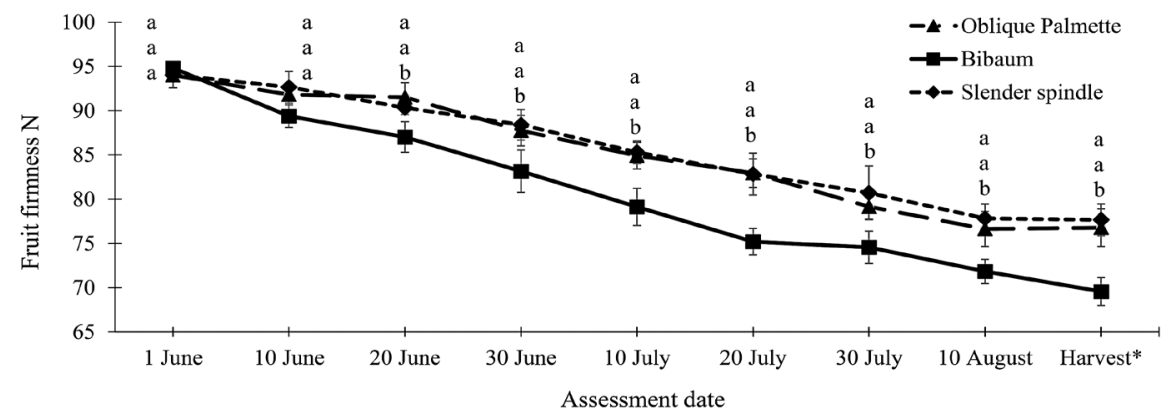

Note. Error bars represent the standard error values; different letters, corresponding to each assessment date, are significantly different form each other for the training systems at $P<0.05$; * - fruits were harvested on 23 and 25 of August of 2015 and 2016 , respectively.

Figure 2. The effect of the three training systems on apple fruit firmness during the assessment period (average data 2015 and 2016)

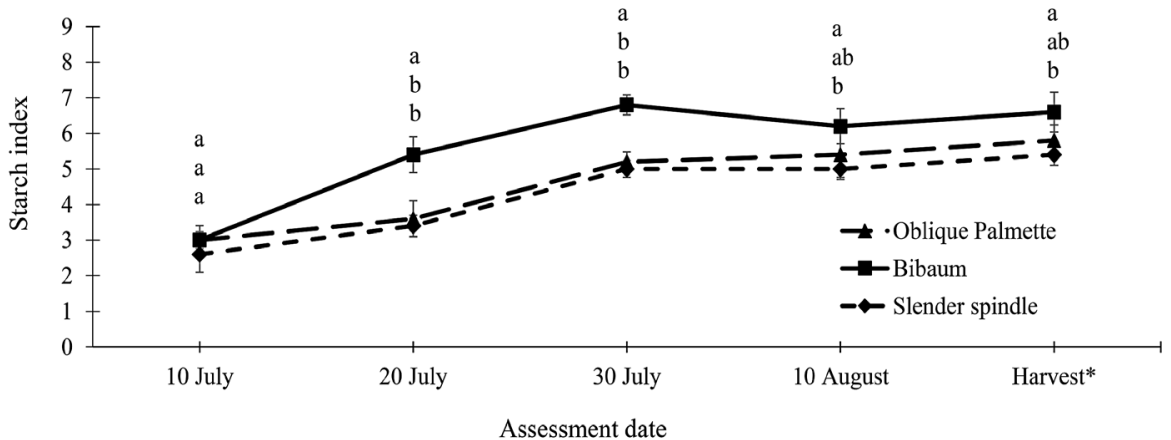

Note. Error bars represent the standard error values; different letters, corresponding to each assessment date, are significantly different form each other for the training systems at $P<0.05$; * - fruit were harvested 23 and 25 of August of 2015 and 2016 , respectively.

Figure 3. The effect of the three training systems on starch index (1-9) of apple fruits during the assessment period (average data 2015 and 2016)

Table 3. The effect of the three training systems on antioxidant capacity related parameters of apple fruits at harvest (average data 2015 and 2016)

\begin{tabular}{lcccc}
\hline Training system & $\begin{array}{c}\text { Ascorbic acid } \\
\mathrm{mg} 100 \mathrm{~g}^{-1}\end{array}$ & $\begin{array}{c}\text { Total anthocyanins } \\
\text { CGE } 100 \mathrm{~g}^{-1} \mathrm{FW}\end{array}$ & $\begin{array}{c}\text { Total antioxidant capacity } \\
\text { mg AA } 100 \mathrm{~g} \mathrm{~g}^{-1} \mathrm{FW}\end{array}$ & $\begin{array}{c}\text { Total soluble phenol content } \\
\text { GAE } 100 \mathrm{~g}^{-1} \mathrm{FW}\end{array}$ \\
\hline Oblique Palmette & $12.0 \mathrm{~b}$ & $17.0 \mathrm{ab}$ & $259.2 \mathrm{ab}$ & 134.3 \\
Bibaum & $11.0 \mathrm{ab}$ & $18.2 \mathrm{~b}$ & $254.7 \mathrm{a}$ & 133.5 \\
Slender Spindle & $10.5 \mathrm{a}$ & $15.8 \mathrm{a}$ & $264.2 \mathrm{~b}$ & 131.2 \\
\multicolumn{1}{c}{ LSD $_{0.05}$} & 1.3 & 2.1 & 5.7 & $\mathrm{~ns}$ \\
\hline
\end{tabular}

Explanation under Table 1; CGE - cyanidin-3-glucoside equivalent, FW - fresh weight, AA - ascorbic acid, GAE - gallic acid equivalent.

amongst treatment factors for the four fruit parameters. Ascorbic acid content of the fruit was the lowest in the Slender Spindle, and it was significantly different only from the Oblique Palmette fruit.

The total anthocyanins of the fruit were the highest in the Bibaum, but significantly different only from the Slender Spindle fruits. The total antioxidant capacity of fruit was the highest in the Slender Spindle, but it was significantly different only from the Bibaum fruits.

Relationships between fruit quality parameters. From the 55 correlation pairs of each training system, 27, 17, and 15 were significant in the Oblique Palmette, the Bibaum and the Slender Spindle, respectively (Table 4).

The strongest significant correlations (above $r=0.8$ ) were found between fruit number and juice acidity for the Oblique Palmette $(r=-0.841)$ and between fruit yield and total anthocyanins, between fruit yield and fruit number, between starch index and soluble solid content and between starch index and juice acidity for the Bibaum $(r=-0.821,0.904,0.912$ and -0.813 , respectively) (Table 4 ). Five correlation pairs were significant in all the three training systems: starch index $v s$ ascorbic acid content, soluble solid content $v s$ total antioxidant capacity, starch index vs soluble solid content, starch index $v s$ fruit firmness, and fruit yield $v s$ fruit number.

The results of the study demonstrated that 16 fruit parameters out of 22 were significantly affected by the evaluated three training systems. The relationship between the 11 yield quality parameters showed several significant correlation pairs, but they varied in the three training systems. Only 5 correlation pairs were significant in all the three training systems (Table 4). 
Table 4. Pearson correlation coefficients between 11 yield quality parameters of apple fruits in the three training systems (average data 2015 and 2016)

\begin{tabular}{|c|c|c|c|c|c|c|c|c|c|c|c|}
\hline Parameter & AA & TA & TSP & TAC & $\mathrm{SSC}$ & JA & $\mathrm{FF}$ & FNT & FW & FYT & SI \\
\hline \multicolumn{12}{|c|}{ Oblique Palmette } \\
\hline AA & 1 & & & & & & & & & & \\
\hline TA & -0.227 & & & & & & & & & & \\
\hline TSP & -0.347 & 0.324 & & & & & & & & & \\
\hline TAC & -0.227 & 0.621 & 0.661 & & & & & & & & \\
\hline $\mathrm{SSC}$ & 0.408 & 0.425 & 0.714 & 0.754 & & & & & & & \\
\hline JA & 0.451 & -0.557 & -0.487 & -0.524 & -0.331 & & & & & & \\
\hline $\mathrm{FF}$ & -0.322 & 0.608 & 0.449 & -0.412 & 0.624 & 0.451 & & & & & \\
\hline FNT & 0.487 & -0.471 & 0.664 & -0.637 & -0.715 & -0.841 & -0.664 & & & & \\
\hline FW & -0.514 & 0.437 & 0.814 & 0.221 & -0.421 & -0.339 & 0.422 & -0.411 & & & \\
\hline YT & 0.622 & -0.233 & 0.701 & -0.314 & -0.521 & -0.691 & -0.324 & 0.544 & -0.441 & & \\
\hline SI & 0.621 & 0.412 & 0.551 & 0.776 & 0.712 & -0.558 & -0.775 & 0.624 & -0.421 & 0.227 & 1 \\
\hline \multicolumn{12}{|c|}{ Bibaum } \\
\hline AA & 1 & & & & & & & & & & \\
\hline TA & -0.322 & & & & & & & & & & \\
\hline TSP & -0.201 & 0.441 & & & & & & & & & \\
\hline TAC & -0.442 & 0.512 & 0.471 & & & & & & & & \\
\hline $\mathrm{SSC}$ & -0.331 & 0.318 & 0.124 & 0.712 & & & & & & & \\
\hline JA & 0.603 & -0.127 & -0.701 & -0.278 & -0.321 & & & & & & \\
\hline $\mathrm{FF}$ & -0.247 & 0.217 & -0.421 & -0.154 & 0.332 & 0.412 & & & & & \\
\hline FNT & 0.662 & -0.712 & 0.425 & -0.321 & -0.420 & -0.211 & -0.451 & & & & \\
\hline FW & -0.112 & 0.201 & 0.321 & 0.421 & -0.314 & -0.334 & 0.772 & -0.321 & & & \\
\hline YT & 0.531 & -0.821 & 0.721 & -0.214 & -0.231 & -0.227 & -0.454 & 0.904 & -0.271 & & \\
\hline SI & 0.721 & 0.721 & 0.558 & 0.421 & 0.912 & -0.813 & -0.775 & 0.305 & -0.321 & 0.449 & 1 \\
\hline \multicolumn{12}{|c|}{ Slender Spindle } \\
\hline AA & 1 & & & & & & & & & & \\
\hline TA & -0.114 & & & & & & & & & & \\
\hline TSP & -0.334 & 0.501 & & & & & & & & & \\
\hline TAC & -0.217 & 0.421 & 0.321 & & & & & & & & \\
\hline $\mathrm{SSC}$ & 0.212 & 0.228 & 0.412 & 0.618 & & & & & & & \\
\hline JA & 0.312 & -0.319 & -0.211 & -0.421 & -0.241 & & & & & & \\
\hline $\mathrm{FF}$ & -0.301 & 0.487 & 0.398 & -0.341 & 0.486 & 0.221 & & & & & \\
\hline FNT & 0.522 & -0.241 & 0.224 & -0.217 & -0.635 & -0.354 & -0.562 & & & & \\
\hline $\mathrm{FW}$ & -0.314 & 0.311 & 0.721 & 0.091 & -0.241 & -0.451 & 0.365 & -0.422 & & & \\
\hline FYT & 0.421 & -0.412 & 0.412 & -0.427 & -0.628 & -0.428 & -0.452 & 0.624 & -0.625 & & \\
\hline SI & 0.512 & 0.211 & 0.421 & 0.627 & 0.638 & -0.234 & -0.598 & 0.594 & -0.621 & 0.421 & 1 \\
\hline
\end{tabular}

Note. Correlation coefficients in bold represent significant correlations at $P<0.05$ level; AA - ascorbic acid, TA - total anthocyanins, TSP - total soluble phenol, TAC - total antioxidant capacity, SSC - soluble solid content, JA - juice acidity, FF - fruit firmness, FNT - fruit number per tree, FW - fruit weight, FYT - fruit yield per tree, SI - starch index.

\section{Discussion}

Light penetration in relation to training systems. In the current study, the light penetration into the tree canopy in May, July and August was significantly different in the training systems (Fig. 1); however, previous studies provided controversial results on the effect of training systems on light availability within the tree. For example, Dallabetta et al. (2017) concluded that training systems resulted in no differences for light availability of the tree; however, in agreement with our study, D'Abrosca et al. (2017) showed that the light interception was affected by various training systems. The results of our study demonstrated that the percentage of fruit colouration was different in studied training systems, as the fruit colour at harvest was the highest in the Bibaum, which was significantly higher than the Oblique Palmette or the Slender Spindle (Table 2). However, the study of D'Abrosca et al. (2017) showed that fruit colouration was similar in the Bibaum, the
Palmette and the Slender Spindle. The differences among the studies can be due to the difference in the tested apple cultivar, the light distribution of the orchard and the tree age. The results of our study demonstrated that not only light penetration and fruit colouration, but also the total anthocyanins content of apple fruit was the highest in the Bibaum (Table 3). This result is in agreement with the previous knowledge that fruit colouration is dependent on anthocyanins concentration of the fruit during maturation as anthocyanins components are responsible for the red pigmentation of the red apple cultivars (Honda, Moriya, 2018).

Sun light is one of the most important environmental factors that increases anthocyanins production and, as a consequence, the fruit colouration of apple fruit (Matsumoto et al., 2018). The light exposure has a great effect in the biosynthesis of most polyphenolic and flavonoid compounds, especially anthocyanins; therefore, fruits exposed to more sun light showed higher anthocyanins content than those grown in the shade 
(Vieira et al., 2011; Feng et al., 2013). In this study, training system provided different light penetration into the tree canopy (Fig. 1) and resulted in a consequent evidence of different anthocyanins content and fruit colouration in the studied training systems (Tables 2 and 3 ).

Fruit yield parameters in relation to training system. The results of the study demonstrated that the fruit yield parameters were different in the three training systems in agreement with several previous studies (Jung, Choi, 2010; D'Abrosca et al., 2017; Reig et al., 2019). In current study, a higher fruit number per tree resulted in a lower fruit weight on the Bibaum trained trees, while in the Slender Spindle a lower fruit number coupled with a larger fruit weight (Table 1). Training systems were shown to affect fruit weight in many previous studies (Jung, Choi, 2010; D’Abrosca et al., 2017). In agreement with the results of our study, D'Abrosca et al. (2017) showed that the Bibaum produced a lower fruit weight in comparison with the Slender Spindle, which was due to the high fruit number per tree in the Bibaum. This result can be due to a greater light penetration into the tree canopy resulting in the formation of more flower buds on the shoots (Jung, Choi, 2010), which reflected in a higher fruit number with lower fruit weight in the Bibaum trained trees in the current study. This study also demonstrated that the higher fruit number reflected in a lower percentage of the fruit size categories of 70 75 and $75-80 \mathrm{~mm}$ in the Bibaum $(23.8 \%$ and $25.8 \%$, respectively) compared to the Slender Spindle (35.4\% and $41.4 \%$, respectively). However, it is noteworthy that Dallabetta et al. (2014) demonstrated that although fruit size was affected by the training system, it was dependent on the cultivar. The authors showed that the Bibaum produced a higher fruit size than the Slender Spindle for 'Galaxy Evolution' apples, while the size for 'Pink Lady' fruits was significantly higher on the Slender Spindle trees compared to the Bibaum.

The higher fruit number increased fruit yield per tree in this study (Table 1), which was supported by a significant positive correlation between fruit number and fruit yield in all the three training systems (Table 4). In addition, the Bibaum produced a significantly higher $(P<0.05)$ fruit yield per hectare $\left(8.56 \mathrm{~kg}^{-1 r e e^{-1} \times 1923}\right.$ tree ha-1 $\left.=16.46 \mathrm{t} \mathrm{ha}^{-1}\right)$ compared to either Slender Spindle $\left(8.23 \mathrm{~kg}\right.$ tree $^{-1} \times 1666$ tree ha $\left.=13.7 \mathrm{t} \mathrm{ha}^{-1}\right)$ or Oblique Palmette $\left(7.4 \mathrm{~kg}\right.$ tree ${ }^{-1} \times 1250$ tree $\left.^{-1}=9.2 \mathrm{t} \mathrm{ha}^{-1}\right)$. This result, in agreement with the previous studies of Gandev et al. (2016) and Vinyes et al. (2018), demonstrated that the high cumulative fruit yield per hectare are largely dependent on the larger number of trees per hectare.

Physico-chemical fruit parameters in relation to training system. Previous studies (Jung, Choi, 2010; Ozkan et al., 2016) reported that fruit firmness inversely correlated to light penetration. The authors demonstrated that soft fruits were obtained from the higher light intensity part of the tree, and the more intensive light sped up the maturation process by increasing the respiration and enhancing the breakdown of starch in the fruit cells. This finding supports the results of this study that the Bibaum trained trees received significantly higher light penetration into the tree canopy, and their fruits showed significantly lower firmness compared to the two other training systems (Figs 1 and 2, Table 2).
Starch accumulates in the fruit during fruit growth as the result of leaf photosynthesis. Starch breakdown starts with the maturity process as a source of sugar needed to support respiration once fruits are detached from the tree (Doerflinger et al., 2015; Mesa et al., 2016; Gonçalves et al., 2017). In this study, the starch index of fruit was significantly higher after 20 July in the fruit of the Bibaum trained trees compared to the two other training systems (Fig. 3), which indicated an earlier breakdown of starch in the Bibaum trees compared to the two other ones.

In the current study, 'Royal Gala' apple fruits were harvested at the usual time for the Central European region; however, fruit colour was more intensive, fruit firmness was lower and the starch index of fruit was higher (i.e. starch concentration was lower) for the fruit harvested from the Bibaum compared to the two other ones (Table 2). This result indicates a possible earlier maturation of fruit in the Bibaum and suggests that fruit maturation and the suitable harvest time are affected by the training systems. This result emphasizes that starchiodine test together with firmness (Gonçalves et al., 2017) has a great importance to determine the suitable harvest dates for each training system.

In the current study, the training system had also an effect on the nutrient accumulations in the leaves, which was in contrast to the study of Afonso et al. (2017), who reported that the effect of training system on the carbohydrate and protein contents of apple leaves showed a little variation. Leaves of the Bibaum trained trees recorded the highest $\mathrm{N}$ - and $\mathrm{K}$-contents with significant differences form the two other training systems (Table 2). It was reported that the light penetration is one of key factor affecting the leaf nutrient content, especially $\mathrm{N}$-content, as the $\mathrm{N}$-content increased with increasing light penetration (Dorigoni et al., 2011). As the light penetration into the tree canopy was higher in the Bibaum compared to the two other training systems (Fig. 1), the higher available light could increase the photosynthetic rate in leaves and enhance the $\mathrm{N}$-content of leaves and the accumulation of carbohydrates in root system, which might increase root system and enhance water and nutrient uptake (Robinson, 2003).

Antioxidant capacity related fruit parameters in relation to training system. Ascorbic acid content of fruit showed slight but significant differences among the training systems, which was in line with the results reported by D'Abrosca et al. (2017) on the effects of training systems on ascorbic acid content in 'Annurca' apple fruits. Another report of Li et al. (2009) showed that an increased exposure of fruit to light enhanced ascorbic acid content in the fruit peel, while no effect was found in fruit flesh. However, we could not corroborate these results as in the current study fruit peel and fruit flesh were not distinguished in the measurements of ascorbic acid content.

The effect of training systems on phenol content of 'Annurca' apple fruits was reported in the previous study of D'Abrosca et al. (2017). The authors demonstrated that fruit with overcolour contains high level of phenolic compounds, which was also confirmed for other apple cultivars (Carbone et al., 2011; Tenore et al., 2013). The red colour of apples is due to anthocyanins content, which represents $1-3 \%$ of total polyphenols in apple fruit (Mari et al., 2010). In this study, the total 
soluble phenol content was not affected by the training system, but anthocyanins content showed differences among the three training systems (Table 3). Differences of our results from previous studies (Vieira et al., 2011; Piagentini, Pirovani, 2017) may be due to the fact that polyphenols content and antioxidant activity are highly dependent on the cultivar.

\section{Correlation between fruit parameters in}

relation to training system. The current study showed significant correlations among several fruit parameters and revealed that the significant correlations between the parameters can be specific to a training system (Table 4). In the previous studies (Saei et al., 2011), a positive correlation was observed between fruit firmness and fruit weight. In this study, this can be confirmed only for the Bibaum. It was also reported that a firmer and denser fruit contained more soluble solids; therefore, fruit firmness and soluble solid content correlated positively (Saei et al., 2011). On the other hand, Ornelas-Paz et al. (2018) showed a negative correlation between fruit firmness and soluble solid content. In the current study, the correlation between fruit firmness and soluble solid content was positive and significant only for the Bibaum.

The differences among the studies can be due to the difference in the tested apple cultivar and/or the applied orchard training system. Significant correlations among anthocyanins content, antioxidant capacity and soluble phenol content were reported in previous studies (Sun et al., 2002; Hülya, 2007), but the results were not related to training systems. Sun et al. (2002) demonstrated that apple cultivars with a large amount of phenolic content had a high antioxidant capacity too. In this study, a significant positive correlation could be demonstrated between antioxidant capacity and phenolic content only for the Oblique Palmette. Hülya (2007) showed a positive correlation between antioxidant capacity and anthocyanins content in red grape cultivars. In this study, a significant positive correlation was shown between antioxidant capacity and anthocyanins content for two (the Oblique Palmette and the Bibaum) out of the three training systems.

\section{Conclusions}

1. The effect of three training systems: Oblique Palmette, Bibaum and Slender Spindle, was investigated on the 22 fruit and leaf parameters of the apple cultivar 'Royal Gala'. The three training systems had significant effect on light penetration into the tree canopy, fruit number per tree, fruit weight, fruit yield, fruit skin colour, fruit firmness, starch index of fruit, $\mathrm{N}$ - and K-contents of leaves as well as ascorbic acid content, total anthocyanins and total antioxidant capacity of fruit.

2 . This study also revealed significant correlations between 11 yield quality parameters: ascorbic acid content, total anthocyanins, total soluble phenol, total antioxidant capacity of fruit, soluble solid concentration, juice acidity, fruit firmness, fruit number per tree, fruit weight, fruit yield per tree and starch index of fruit, in the three training systems. From the 55 correlation pairs, 5 were significant in all the three training systems: starch index $v s$ ascorbic acid content, soluble solid concentration $v s$ total antioxidant capacity, starch index $v s$ soluble solid concentration, starch index $v s$ fruit firmness and fruit yield $v s$ fruit number.
3. The results of this study provide a better knowledge of fruit yield and quality differences among the training systems under climate conditions similar to the Central European region, which may influence apple growing practices and fruit quality in a given orchard training system.

\section{Acknowledgments}

This work was partly financed by the Hungarian Scientific Research Fund (K 131478) by a J. Bolyai Research Fellowship awarded to I. J. Holb, by the European Union and the State of Hungary, co-financed by the European Social Fund in the framework of TÁMOP4.2.4.A/ 2-11/1-2012-0001 National Excellence Program under project No. A2-SZJ-TOK-13-0061, and by the Thematic Excellence Programme of the Ministry for Innovation and Technology in Hungary (ED_18-12019-0028), within the framework of the climate change thematic programme of the University of Debrecen.

The authors wish to thank the great co-operation of A. Illés for the field preparation of this work and É. Domokos Szabolcsy and J. Prokisch for the assistance with the laboratory work of fruit samples.

Received 23012020

Accepted 22062020

\section{References}

1. Afonso S., Ribeiro C., Bacelar E., Ferreira H., Oliveira I., Silva A. P., Gonçalves B. 2017. Influence of training system on physiological performance, biochemical composition and antioxidant parameters in apple tree (Malus domestica Borkh.). Scientia Horticulturae, 225: 394-398. https://doi.org/10.1016/j.scienta.2017.07.037

2. Ainsworth E. A., Gillespie K. M. 2007. Estimation of total phenolic content and other oxidation substrates in plant tissues using Folin-Ciocalteu reagent. Nature Protocols, 2 (4): 875-877. https://doi.org/10.1038/nprot.2007.102

3. Al-Ani M., Opara L. U., Al-Bahri D., Al-Rahbi N. 2007. Spectrophotometric quantification of ascorbic acid contents of fruit and vegetables using the 2,4-dinitrophenylhydrazine method. Journal of Food Agriculture and Environment, 5 (3-4): 165-168.

4. Carbone K., Giannini B., Picchi V., Scalzo R. L., Cecchini F. 2011. Phenolic composition and free radical scavenging activity of different apple varieties in relation to the cultivar, tissue type and storage. Food Chemistry, 127 (2): 493-500. https://doi.org/10.1016/j.foodchem.2011.01.030

5. Crassweller R. M., Smith D. E. 2017. Early results of tree training system on production of two apple cultivars. Acta Horticulturae, 1177: 127-132.

https://doi.org/10.17660/ActaHortic.2017.1177.16

6. D'Abrosca B., Scognamiglio M., Corrado L., Chiocchio I., Zampella, L. Mastrobuoni F., Petriccione M. 2017. Evaluation of different training systems on Annurca apple fruits revealed by agronomical, qualitative and NMR-based metabolomic approaches. Food Chemistry, 222: 18-27. https://doi.org/10.1016/j.foodchem.2016.11.144

7. Dallabetta N., Costa F., Pasqualini J., Noferini M., Costa G. 2014. The influence of training system on apple fruit quality. Acta Horticulturae, 1058: 55-62. https://doi.org/10.17660/ActaHortic.2014.1058.4

8. Dallabetta N., Costa F., Guerra A., Pasqualini J., Giordan M., Zorer R., Wehrens R., George E., Magnanini E., Costa G. 2017. Effects of light availability and training systems on apple fruit quality. Acta Horticulturae, 1160: 237-244. https://doi.org/10.17660/ActaHortic.2017.1160.35

9. Doerflinger F. C., Miller W. B., Nock J. F., Watkins C. B. 2015. Variations in zonal fruit starch concentrations of apples - a developmental phenomenon or an indication of ripening? Horticulture Research, 2: 15047. https://doi.org/10.1038/hortres.2015.47 
10. Dorigoni A., Lezzer P., Dallabetta N., Serra S., Musacchi S. 2011. Bi-axis: an alternative to slender spindle for apple orchards. Acta Horticulturae, 903: 581-588. https://doi.org/10.17660/ActaHortic.2011.903.80

11. Fallahi E., Kiester M. J., Fallahi B., Mahdavi S. 2018. Rootstock, canopy architecture, bark girdling, and scoring influence on growth, productivity, and fruit quality at harvest in 'Aztec Fuji' apple. HortScience, 53 (11): 1629 1633. https://doi.org/10.21273/HORTSCI13348-18

12. Feng F., Li M., Ma F., Cheng L. 2013. Phenylpropanoid metabolites and expression of key genes involved in anthocyanin biosynthesis in the shaded peel of apple fruit in response to sun exposure. Plant Physiology and Biochemistry, 69: 54-61. https://doi.org/10.1016/j.plaphy.2013.04.020

13. Gandev S., Dzhuvinov V. 2014. Training and pruning of apple and modern trends of development - an overview. Turkish Journal of Agricultural and Natural Sciences, 1: 1264-1267.

14. Gandev S., Nanev I., Savov P., Isuf E., Kornov G., Serbezova D. 2016. The effect of three training systems on the vegetative and reproductive habits of the apple cultivar 'Braeburn' grafted on M9 rootstock. Bulgarian Journal of Agricultural Science, 22 (4): 600-603.

15. Gonçalves M. W., Argenta L. C., Martin M. S. D. 2017. Maturity and quality of apple fruit during the harvest period at apple industry. Revista Brasileira de Fruticultura, 39 (5): e-825. https://doi.org/10.1590/0100-29452017825

16. Holb I. J., Dremák P., Bitskey K., Gonda I. 2012. Yield response, pest damage and fruit quality parameters of scabresistant and scab-susceptible apple cultivars in integrated and organic production systems. Scientia Horticulturae, 145: 109-117. https://doi.org/10.1016/j.scienta.2012.08.003

17. Honda C., Moriya S. 2018. Anthocyanin biosynthesis in apple fruit. The Horticulture Journal, 87: 305-314. https://doi.org/10.2503/hortj.OKD-R01

18. Hülya O. H. 2007. Total antioxidant activities, phenolics, anthocyanins, polyphenoloxidase activities of selected red grape cultivars and their correlations. Scientia Horticulturae, 111: 235-241. https://doi.org/10.1016/j.scienta.2006.10.019

19. Jung S. K., Choi H. S. 2010. Light penetration, growth, and fruit productivity in 'Fuji' apple trees trained to four growing systems. Scientia Horticulturae, 125 (4): 762-678. https://doi.org/10.1016/j.scienta.2010.05.027

20. Li M., Ma F., Shang P., Zhang M., Hou C., Liang D. 2009. Influence of light on ascorbate formation and metabolism in apple fruits. Planta, 230 (1): 39-51. https://doi.org/10.1007/s00425-009-0925-3

21. Mari A., Tedesco I., Nappo A., Russo G. L., Malorni A., Carbone V. 2010. Phenolic compound characterisation and antiproliferative activity of 'Annurca' apple, a southern Italian cultivar. Food Chemistry, 123: 157-164. https://doi.org/10.1016/j.foodchem.2010.04.023

22. Matsumoto K., Kobayashi T., Kougo T., Fujita T., Sato S., Moriguchi T. 2018. Sunlight differentially affects the fruit skin, flesh, and core coloration of the type 2 red-fleshed apple 'Kurenainoyume': optimization of fruit bagging treatment. The Horticulture Journal, 87 (4): 462-473. https://doi.org/10.2503/hortj.OKD-120

23. Mesa K., Serra S., Masia A., Gagliardi F., Bucci D., Musacchi S. 2016. Seasonal trends of starch and soluble carbohydrates in fruits and leaves of 'Abbé Fétel' pear trees and their relationship to fruit quality parameters. Scientia Horticulturae, 211: 60-69. https://doi.org/10.1016/j.scienta.2016.08.008

24. Ornelas-Paz J. D. J., Quintana-Gallegos B. M., EscalanteMinakata P., Jaime Reyes-Hernández J. D., PérezMartínez C., Rios-Velasco S., Ruiz C. 2018. Relationship between the firmness of Golden Delicious apples and the physicochemical characteristics of the fruits and their pectin during development and ripening. Journal of Food Science and Technology, 55: 33-41. https://doi.org/10.1007/s13197-017-2758-6
25. Oszmiański J., Nowicka P., Teleszko M., Wojdyło A., Cebulak T., Oklejewicz K. 2015. Analysis of phenolic compounds and antioxidant activity in wild blackberry fruits. International Journal of Molecular Sciences, 16 (7): 14540-14553. https://doi.org/10.3390/ijms160714540

26. Ozkan Y., Yildiz K., Kucuker E., Cekic C., Ozgen M., Akca Y. 2016. Performance of 'Fuji' apple on M.9 rootstock in different tree training systems for the first five years. Journal of Agricultural Science and Technology 18: 16471653. https://jast.modares.ac.ir/article-23-1822-en.html

27. Piagentini A. M., Pirovani M. E. 2017. Total phenolics content, antioxidant capacity, physicochemical attributes, and browning susceptibility of different apple cultivars for minimal processing. International Journal of Fruit Science, 17 (1): 102-116. https://doi.org/10.1080/15538362.2016.1262304

28. Qin C., Li Y., Niu W., Ding Y., Zhang R., Shang X. 2010. Analysis and characterisation of anthocyanins in mulberry fruit. Czech Journal of Food Sciences, 28 (2): 117-126. https://doi.org/10.17221/228/2008-CJFS

29. Reig G., Lordan J., Sazo M. M., Hoying S., Fargione M., Reginato G., Donahue D. J., Francescatto P., Fazio G., Robinson T. 2019. Long-term performance of 'Gala', Fuji' and 'Honeycrisp' apple trees grafted on Geneva ${ }^{\circledR}$ rootstocks and trained to four production systems under New York State climatic conditions. Scientia Horticulturae, 244: 277-293. https://doi.org/10.1016/j.scienta.2018.09.025

30. Robinson T. L. 2003. Apple-orchard planting systems. Ferree D. C., Warrington I. J. (eds). Apples: botany, production and uses. CABI Publishing, p. 345-408. https://doi.org/10.1079/9780851995922.0345

31. Saei A., Tustin D. S., Zamani Z., Talaie A., Hall A. J. 2011. Cropping effects on the loss of apple fruit firmness during storage: the relationship between texture retention and fruit dry matter concentration. Scientia Horticulturae, 130: 256-265. https://doi.org/10.1016/j.scienta.2011.07.008

32. Sander G. F., Macedo T. A., da Silva P. S., Welter J. F., Posser A. J., Rufato L., Kretzschmar A. A. 2019. Effect of different training systems to catch greater light interception in apple cultivar Maxi Gala in temperate climate. Australian Journal of Crop Science, 13 (4): 574-577. https://doi.org/10.21475/ajcs.19.13.04.p1542

33. Sun J., Chu Y., Wu X., Liu R. H. 2002. Antioxidant and antiproliferative activities of common fruits. Journal of Agricultural and Food Chemistry, 50: 7449-7454. https://doi.org/10.1021/jf0207530

34. Tenore G. C., Campiglia P., Ritieni A., Novellino E. 2013. In vitro bioaccessibility, bioavailability and plasma protein interaction of polyphenols from Annurca apple (Malus pumila Miller cv. Annurca). Food Chemistry, 141 (4): 3519-3524. https://doi.org/10.1016/j.foodchem.2013.06.051

35. Vieira F. G. K., Borges G. D. S. C., Copetti C., Di Pietro P. F., da Costa Nunes E., Fett, R. 2011. Phenolic compounds and antioxidant activity of the apple flesh and peel of eleven cultivars grown in Brazil. Scientia Horticulturae, 128 (3): 261-266. https://doi.org/10.1016/j.scienta.2011.01.032

36. Vinyes E., Asin L., Alegre S., Gasol C. M., Muñoz P. 2018. Carbon footprint and profitability of two apple cultivation training systems: central axis and fruiting wall. Scientia Horticulturae, 229: 233-239. https://doi.org/10.1016/j.scienta.2017.10.046

37. Wertheim S. J., Wagenmakers P. S., Bootsma J. H., Groot M. J. 2001. Orchard systems for apple and pear: conditions for success. Acta Horticulturae, 557: 209-227. https://doi.org/10.17660/ActaHortic.2001.557.28

38. Yang S., Xing S., Liu C., Du Z., Wang H., Xu Y. 2010. Effects of root pruning on the vegetative growth and fruit quality of Zhanhuadongzao trees. Horticultural Science, 37 (1): 14-21. https://doi.org/10.17221/29/2009-HORTSCI 
ISSN 1392-3196 / e-ISSN 2335-8947

Zemdirbyste-Agriculture, vol. 107, No. 4 (2020), p. 373-382

DOI 10.13080/z-a.2020.107.048

\title{
Obels vaisių ir lapų rodiklių palyginimas taikant tris vaismedžių formavimo sistemas
}

\author{
A. Ezzat ${ }^{1}$, A. R. El-Sherif ${ }^{1}$, D. Elgear ${ }^{1}$, S. Szabó ${ }^{2}$, I. J. Holb H,4 $^{3,4}$ \\ ${ }^{1}$ Kafelelsehikh universiteto Žemès ūkio fakultetas, Egiptas \\ ${ }^{2}$ Debreceno universiteto Fizikinès geografijos ir geoinformatikos skyrius, Vengrija \\ ${ }^{3}$ Debreceno universiteto Agronomijos fakulteto Sodininkystès institutas, Vengrija \\ ${ }^{4}$ Vengrijos mokslų akademijos Žemès ūkio tyrimų centro Augalų apsaugos institutas
}

\section{Santrauka}

Dvejų metų bandymo, atlikto su veislès 'Royal Gala' vaismedžiais, metu tirta trijų obels medžių formavimo sistemų įtaka vaisių ir lapų rodikliams: 9 vaisių derliaus, 8 fizikocheminiams bei 4 antioksidacinès gebos parametrams, ir ryšiai tarp 11 derliaus kokybès rodiklių. Be to, buvo tirtas šviesos prasiskverbimas i obelų lajos dangą. Tirtos trys obels formavimo sistemos: ịstrižinė palmetė (Oblique Palmette) (1250 medžių ha ${ }^{-1}$ ), Bibaum (1923 medžiu ha $\left.{ }^{-1}\right)$ ir laiboji verpstè (Slender Spindle) (1666 medžiu ha $\left.{ }^{-1}\right)$. Šviesos prasiskverbimas i laja, vaisiu kiekis iš obels, derlius, vaisiaus svoris, luobelès spalva, tvirtumas, krakmolo indeksas, askorbo rūgšties kiekis, suminis antocianinų kiekis ir antioksidacine geba ir $\mathrm{N}$ bei $\mathrm{K}$ kiekiai lapuose reikšmingai $(P<0,05)$ skyrèsi tarp obels formavimo sistemu, tačiau skirtumai tarp metu nebuvo reikšmingi. Taikant Bibaum sistemą suformuotos obelys turejo didžiausias šviesos prasiskverbimo ị lają, derliaus, vaisių kiekio iš obels, luobelès spalvos, krakmolo indekso, suminio antocianinu kiekio ir N ir K kiekio lapuose vertes, kurios reikšmingai skyrèsi nuo šių rodikliu verčių Oblique Palmette ir Slender Spindle sistemose. Slender Spindle sistema pasižymèjo didžiausiomis vaisiaus svorio, tvirtumo ir bendros oksidacinès gebos vertėmis, kurios reikšmingai skyrėsi nuo šių rodiklių verčių Bibaum sistemoje. Vaisiai obelų, suformuotų taikant Oblique Palmette sistemą, turèjo didžiausią askorbo rūgšties kiekị, kuris reikšmingai skyrèsi nuo vaisų obelų, suformuotų Slender Spindle sistema, tačiau reikšmingai nesiskyrè nuo Bibaum sistema formuotu obelu vaisių. Iš 55 Oblique Palmette, Bibaum ir Slender Spindle obels formavimo sistemų koreliacijos porų reikšmingos buvo atitinkamai 27,17 ir $15(P<0,05)$. Tik penkios koreliacijų poros buvo reikšmingos taikant visas tris obels formavimo sistemas.

Tyrimo rezultatai atskleidè, kad daugumai tirtų rodiklių didelę įtaką turejjo obels formavimo sistemos, kurios gali turèti didelès reikšmès obuolių auginimo praktikai ir vaisių kokybei atskirame sode.

Reikšminiai žodžiai: antioksidacinė geba, augalų sveikatos būklè, derliaus rodikliai, formavimo sistema, šviesos prasiskverbimas, vaisių kokybės rodikliai. 